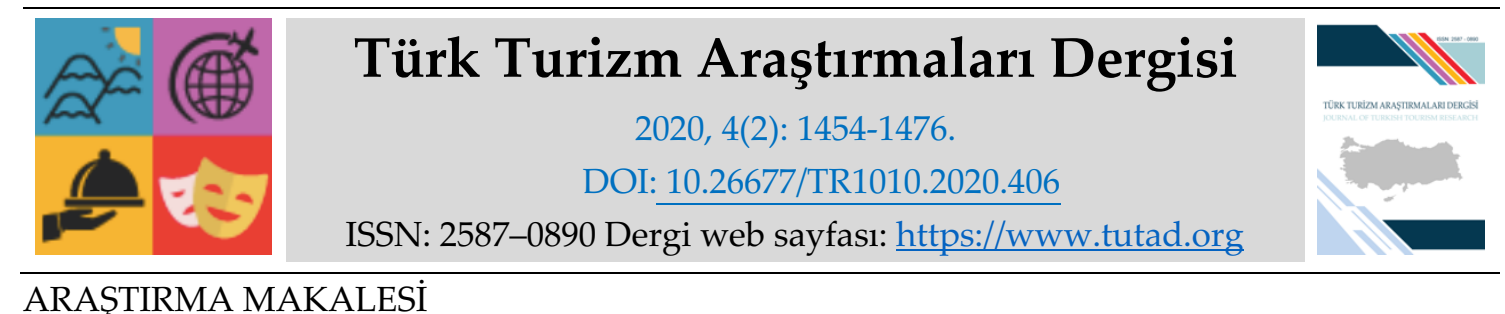

ARASTIRMA MAKALESI

\title{
Deneyimsel Pazarlamanın Tüketicilerin Deneyimsel Memnuniyeti ve Tavsiye Etme Niyetine Etkisi: Samsun Golf Kulübü Örneği*
}

Doç. Dr. Mustafa Kemal YILMAZ, Samsun Üniversitesi, İktisadi ve İdari Bilimler Fakültesi, Samsun, e-posta: mustafa.yilmaz@samsun.edu.tr ORCID: https://orcid.org/0000-0002-6906-5414

Ali VAHIDLİ, Yüksek Lisans Öğrencisi, Ondokuz Mayıs Üniversitesi, Sosyal Bilimler Enstitüsü, Samsun, e-posta: vahidliali@outlook.com

ORCID: https://orcid.org/0000-0003-1522-216X

Öz

Geleneksel pazarlamaya kıyasla daha yenilikçi ve yaratıcı bir yaklaşım olan deneyimsel pazarlama, sadece tüketici istek ve ihtiyaçlarını göz önünde bulundurmaz, aynı zamanda tüketim sürecini eşsiz bir deneyim haline getirmeyi de amaçlar. Ekonomik değer dizisinin en üst çıtısı olan deneyim, artık kişiselleştirmenin daha ötesine geçerek ve tüketici ile daha çok iş birliğine dayanarak, tüketicinin hem tasarım hem üretim süreci içerisinde bulunmasını öngörmektedir. Bu çalışma, deneyimsel pazarlama faaliyetleri sonucu tüketicilerin yaşadıkları deneyimlerin, deneyim memnuniyeti ve başkalarına tavsiye etme niyetine yönelik etkilerini incelemek amacıyla yapılmıştır. Araştırmada kullanılan veriler, Samsun Golf Kulübünde golf oynayan oyunculara anket uygulanarak elde edilmiştir. Anket yöntemi ile elde edilen veriler, IBM SPSS 22 ve Smart PLS 3.0 istatistik paket programları kullanılarak analiz edilmiştir. Araştırma sonucunda, deneyimsel pazarlama boyutlarından duygusal ve davranışsal deneyimlerin deneyimsel memnuniyeti olumlu yönde etkilediği; ancak duyusal, düşünsel ve ilişkisel deneyimlerin deneyimsel memnuniyeti etkilemediği ortaya çıkmıştır. Araştırmada elde edilen diğer bir bulgu ise, deneyimsel pazarlama boyutlarından duygusal ve ilişkisel deneyimlerin tavsiye etme niyetini olumlu yönde etkilediğini; duyusal, davranışsal ve düşünsel deneyimlerin ise, tavsiye etme niyetini etkilemediğini ortaya koymuştur. Son olarak deneyimsel memnuniyetin tavsiye etme niyetini olumlu yönde etkilediği sonucuna ulaşılmıştır.

* Bu çalışma, Ondokuz Mayıs Üniversitesi Sosyal Bilimler Enstitüsü İşletme Anabilim Dalında hazırlanan yüksek lisans tezinden türetilmiştir.

Anahtar Kelimeler: Deneyimsel Pazarlama, Deneyimsel Memnuniyet, Tavsiye Etme Niyeti, Samsun Golf Kulübü.

Makale Gönderme Tarihi: 19.01.2020

Makale Kabul Tarihi: 06.04.2020

Önerilen Atıf:

Yılmaz, M. K. ve Vahidli, A. (2020). Deneyimsel Pazarlamanın Tüketicilerin Deneyimsel Memnuniyeti ve Tavsiye Etme Niyetine Etkisi: Samsun Golf Kulübü Örneği, Türk Turizm Araştırmaları Dergisi, 4(2): 14541476.

(C) 2020 Türk Turizm Araştırmaları Dergisi. 


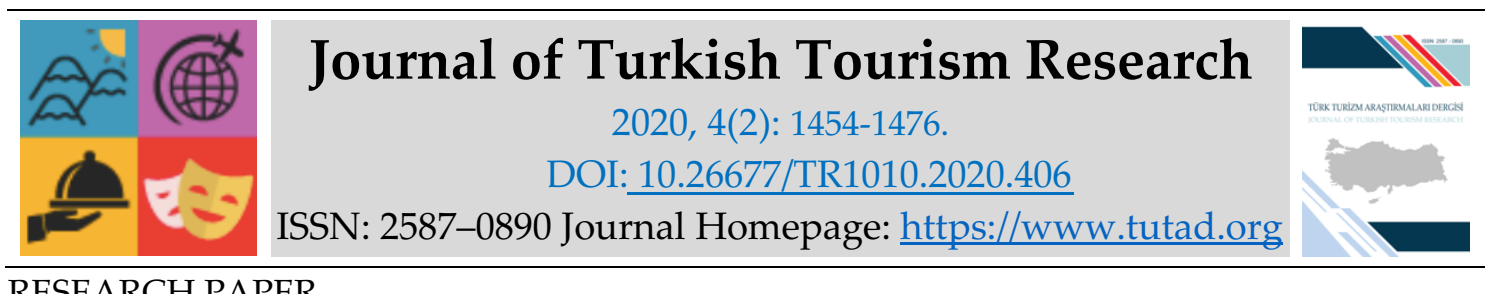

RESEARCH PAPER

\title{
The Effect of Experiential Marketing on Consumers' Experiential Satisfaction and Intention to Recommend: Samsun Golf Club Example
}

Associate Prof. Dr. Mustafa Kemal YILMAZ, Samsun University, Faculty of Economics and Administrative Sciences, Samsun, e-mail: mustafa.yilmaz@samsun.edu.tr ORCID: https://orcid.org/0000-0002-6906-5414

Ali VAHIDLI, MSc. Student, Ondokuz Mayıs University, Graduate School of Social Sciences, Samsun, e-mail: vahidliali@outlook.com ORCID: https://orcid.org/0000-0003-1522-216X

\begin{abstract}
Compared to traditional marketing, experiential marketing which is a more innovative and creative approach, not only considers the consumer's wishes and needs but also aims to make the consumption process a unique experience. The experience, which is the highest output of the economic value sequence, now goes beyond personalization, it envisages the consumer to be involved in both the design and production process by being based on more corporation with the consumer. This study was conducted to examine the effects of consumers' experiences on the experiential satisfaction and intention of recommending and them to others as a result of experiential marketing activities. The data used in the research were obtained by applying a survey to the players playing golf at Samsun Golf Club. The data obtained by the survey were analyzed using IBM SPSS 22 and Smart PLS 3.0 statistical package programs. As a result of the research, it was seen that emotional and behavioral experiences included in the experiential marketing dimensions had a positive effect on experiential satisfaction; however, it was revealed that sensory, thoughtful and relational experiences did not affect the experiential satisfaction. Another finding obtained from the research indicates that positively have while affecting the intention to recommend emotional and relational experiences from experiential marketing dimensions; sensory, behavioral and ideational experiences have been found not to affect the intention to recommend. Finally, it was concluded that experiential satisfaction positively affects the intention to recommend.
\end{abstract}

Keywords: Experiential Marketing, Experiential Satisfaction, Intention to Recommend, Samsun Golf Club Received: 19.01 .2020

Accepted: 06.04.2020

Suggested Citation:

Yilmaz, M. K. and Vahidli, A. (2020). The Effect of Experiential Marketing on Consumers' Experiential Satisfaction and Intention to Recommend: Samsun Golf Club Example, Journal of Turkish Tourism Research, 4(2): 1454-1476.

(C) 2020 Türk Turizm Araştırmaları Dergisi. 


\section{GİRIŞ}

1990'lı yıllarla birlikte ekonomik faaliyetlerde deneyim yaratmaya yönelik bir yapı sunan deneyim ekonomisi, deneyimsel pazarlamayı gündeme getirmiş, geleneksel pazarlamanın demode olmuş, can sıkan uygulamalarına heyecan ve eğlence katarak değişim rüzgarlarını başlatmıştır. 2000'li yıllar ile birlikte ise teknoloji alanında yaşanan ilerlemelere bağlı olarak gelişen, iletişim ve reklam araçlarının yaygınlaşması tüketici karar ve tercihlerinde geleneksel pazarlama anlayışının yetersiz kalmasına neden olmuştur.

Pazarlama ve iş dünyası için yeni bir yaklaşım olan deneyimsel pazarlama, geleneksel pazarlama gibi müşterileri rasyonel karar vericiler olarak görüp, sadece ürünün fonksiyonel özelliklerine ve faydalarına odaklanarak sonuca gitmeyi hedeflemez. Aksine, deneyimsel pazarlama esas olarak müşterileri rasyonel ve duygusal karar vericiler olarak değerlendirerek, ürün ya da hizmete ilişkin tüketicide bütüncül bir deneyim yaratmayı amaçlamaktadır. Bu nedenle, bugünün tüketicileri sadece işlevsel kullanımlarına dayalı olarak ürün veya hizmet satın almamakta, aynı zamanda sunulan ürün veya hizmetlerle ilgili deneyimleri de dikkate almaktadırlar. Bu çerçevede deneyimsel pazarlama, pazarlanan ürün veya hizmetlerle tüketicilerin dikkatini çekerek tüketicilerin kalplerine ve zihinlerine dokunan, onlarda unutamayacakları deneyimleri sahneleyen bir pazarlama anlayışıdır. Müşteri deneyimine odaklanan deneyimsel pazarlama, doğrudan müşteri içeren ve onlara bir işletmenin gelişimine katılmaları için ilham veren bir tür pazarlama inovasyonudur.

Değişimden hoşlanan, yeni nesil tüketiciler; onları dinleyen, onlarla iş birliğine giren hem tasarım hem üretim sürecinde kendilerine yer vererek kişiselleştirmenin de ötesine geçen, iç dünyalarında unutamayacakları benzersiz deneyimler sahneleyen işletmeleri tercih etmekte ve onlarla duygusal bir bağlantı kurmaktadırlar. Dolaylısıyla artık tüketicilerin ürünlerle değil ürünlerin kendi dünyalarında fark yaratan anlamlarına para verdikleri görülmektedir. $\mathrm{Bu}$ fikirden hareketle çalışma, tüketicilerin yaşayabileceği beş ayrı pazarlama deneyiminin (duyusal, duygusal, düşünsel, davranışsal ve ilişkisel) deneyimsel memnuniyete ve tavsiye etme niyetine etkilerinin incelenmesini amaçlamaktadır. Araştırmanın diğer amaçları; Deneyimsel pazarlama boyutlarının (duyusal, duygusal, düşünsel, davranışsal ve ilişkisel deneyimin) kulüp tarafından nasıl sunulduğunu, Deneyimsel pazarlama boyutlarının deneyimsel memnuniyete ve tavsiye etme niyetine etkisini, Deneyimsel memnuniyetin tavsiye etme niyetine etkisini, Deneyimsel pazarlama boyutlarının deneyimsel memnuniyet aracılığıyla tavsiye etme niyetine etkisini, oyuncuların memnuniyet ve tavsiye etme düzeylerini belirlemektir.

Çalışmanın Samsun Golf Kulübü'nden hizmet alan golfçülerin yaşadığı deneyimleri belirleyerek, bu deneyimleri başkalarına tavsiye etmelerinde etkili olan önemli deneyim sunumlarının tespit edilmesine katkı sağlaması beklenilmektedir. Ayrıca deneyimsel pazarlama faaliyetleri ile ilgili yerli literatürde birçok alanda çalışmalar yapılsa da golf hizmetleri ile ilgili öncü olan bu çalışma: hem literatürü zenginleştirme bakımından hem de golf hizmetleri gibi özel ve dikkat çekici alanların çalışmalara konu edilmesi açısından önem arz etmektedir. Bunun yanı sıra araştırmanın güçlü bir turizm kenti oluşturma potansiyeline sahip olan Samsun ilinin şehir pazarlaması çalışmalarına veri sağlayacak nitelikte olacağı öngörülmektedir.

\section{KAVRAMSAL ÇERÇEVE Deneyimsel Pazarlama}

Günümüzde müşterilerin, birçok kanaldan çok sayıda reklam mesajına maruz kalması, her ne kadar işletmeler ile müşterileri sıklıkla fiziksel veya sanal olarak karşılaştırsa da aralarındaki 
psikolojik mesafelerin açılmasına ve müşterilerin markalara karşı hem duyarsız ve hem de ilgisiz hale gelmesine yol açmaktadır. Yoğun iletişim bombardımanına tutulan müşteri, çoğunlukla ürün veya hizmetlerin fonksiyonel faydasına ilişkin bir değerlendirme yapmak istememektedir. Hal böyleyken işletmeler, kendilerine çıkış yolu yaratma sürecinde müşteriyle etkileşime geçerek müşteriye özgü, kişinin duygularına, iç dünyasına dokunan, hafızasından silinmeyecek bir değer önerisi olarak deneyimin oluşturulmasının gerekliliğini anlamışlardır. Şöyle ki, günümüz tüketicisi alışveriş ve tüketim olgusunu bütünsel bir süreç şeklinde algılamaktadır. Nitekim tüketiciler "satın alım öncesi, anı ve sonrası" etaplarına aktif olarak katılmayı istemekte ve bu sürecin zevkli, neşeli bir deneyim olduğunu düşünmektedirler (Deligöz, 2016: 7). Kuşkusuz, pazarlama yönetimi de müşterileri tüketim deneyimlerinde "katılım, etkileşim ve eğlence" gibi özellikler için planlar yapmaya ve gerçekleştirmeye yönelmektedir (Holbrook, 2000: 185). Bu anlayışla işletmeler için deneyimsel pazarlama, büyümenin ve sürdürülebilirliğin anahtarı olmuştur.

Deneyimsel Pazarlamanın temel parçası olarak ele alınan deneyim, her ne kadar bir pazarlama taktiği olarak oluşturulmuş olsa da "Deneyimsel Pazarlama" kavramına ilişkin detaylı bilgi Columbia Business School pazarlama profesörü Bernd Schmitt tarafından ortaya konulmuş ve deneyimsel pazarlamanın kurucusu olarak adlandırılmasına vesile olmuştur (Wang, Chen, Fan ve $\mathrm{Lu}, 2012:$ 1765). Schmitt deneyimsel pazarlamayı, mal ve hizmetlerin müşteriye sağladığ fonksiyonel özellik ve fayda odağındaki sınırlılı̆̆ın aksine, müşterilerin deneyimlerine odaklanan daha bütüncül bir yaklaşım olarak tanımlamaktadır (Schmitt, 1999a: 57). Dolaylısıyla işletmeler, fonksiyonellikten ziyade duygusal ve sembolik değerler arayan müşterileri, duygusal olarak tatmin etmek için adımlar atmaktadırlar. Burada önemli bir husus, işletmelerin müşteriler ile kurdukları etkileşimler ile oluşturdukları faaliyetlerin dikkatli bir şekilde tasarlanması ve müşteriye sunulmasıdır. Tüm satıcılar hizmet sunmaktadır; zorlayıcı olan ise müşterinize hafızasından silinmeyecek bir deneyimde eşlik etmektir (Kotler, 2017: 30). Çünkü müşterinin ancak iç dünyasına hitap eden bir duruma/faaliyete para vereceği aşikardır.

Bernd Schmitt'i takiben deneyimsel pazarlamanın alt yapısını oluşturan deneyim ekonomisi kavramını ortaya çıkaran Pine ve Gilmore, deneyimsel pazarlamayı; bir yaşam deneyimi yaratmak için yapılan tüketicinin katıldığı, meşgul olduğu, edindiği ve tükettiği bir olgu veya olgular zinciri olarak tanımlamışlardır (2001:10). Ayrıca Pine ve Gilmore "pazarlamanın amacının, satışı gereksiz hale getirmek" olduğunu belirten Peter Drucker'a ilave olarak "deneyimin amacının pazarlamayı gereksiz hale getirmek" olduğunu söyleyerek deneyimsel pazarlamanın varlığı üzerinde durmaktadırlar (Gilmore ve Pine, 2002: 8). Ayrıca sunmuş oldukları değer önerilerinin pazarda talep görmesini isteyen işletmelerin, etkileyici, sağlam, unutulmaz ve ilgi çekici bir deneyim yaratması gerektiğini vurgulamaktadırlar.

Bir kerelik deneyimden daha fazlası olan deneyimsel pazarlamanın, pazarlama hakkında düşünmenin yeni bir yolu olduğu ifade edilmektedir. Deneyimsel pazarlama, spesifik bir yöntem değil, pazarlamaya yeni bakıştır. Deneyimsel pazarlama güncel pazarlama ortamına bağlı olarak gelişen bir pazarlama inovasyonudur (Batı, 2018: 22-23). Bu bağlamda dönüşüme uğrayan pazarlama departmanı, müşterilerin kalpleri olan duygusal varlıklar olduğu anlayışından hareketle, onların kalplerine dokunan değer önerilerinin gerekliliğiyle hareket etmeye başlamışlardır (Lagiewski ve Zekan, 2006: 165). Böylelikle, işletmelerin odaklanması gereken nokta, mal veya hizmetlerin müşterilerle birbirilerine duygusal olarak bağlanması olurken, deneyimsel pazarlamada anahtar unsur duygusal bağlllıktır (McCole, 2004: 535). Sadece müşteri sadakatine odaklanan geleneksel pazarlama yaklaşımı, deneyim ekonomisine uyum sağlayamayacağı için deneyimsel pazarlamanın ileriye sürdüğü duygusal bağlılık öne çıkarılması gereken bir parametre olmaktadır. Böylelikle, işletmelerin sunmuş oldukları değer 
önerileriyle sağlanan müşteri sadakatinin, benzersiz ve keyifli deneyimlerin artırılması ile gerçekleştirilebileceği ifade edilebilir (Tsai, 2005: 433).

Schmitt 1999 yılında kaleme aldığı makalesinde, deneyimsel pazarlamanın geleneksel pazarlamaya muhalif bir görüş olduğunu belirtmiş ve deneyimsel pazarlamayı geleneksel pazarlamadan ayıran bazı temel özelliklerin olduğunu söylemiştir. Ayrıca Schmitt, müşteriler için oluşturulan "özellik-fayda" eksenindeki geleneksel pazarlamanın, müşteriler için oluşturulan "deneyim" eksenindeki deneyimsel pazarlamaya doğru evrilmeyi üç gelişmenin sonucu olarak ifade etmiştir (Schmitt, 1999a: 53-54).

$\mathrm{Bu}$ gelişmelerin ilki, bilgi teknolojilerinin hızla yaygınlaşması ile ortaya çıkmıştır. Teknolojik olarak cep telefonlarının, bilgisayarların kameralarla donatılmasıyla birlikte, insanlar ve kurumlar arasındaki bağlantı ve paylaşımlar istenilen yer ve zamanda gerçekleşir hale gelmiştir. İkinci gelişme, marka vurgusunun öne çıması olmuştur. Ürün ve hizmetlerin işlevsel özelliklerinden çok müşteri deneyimlerinin oluşturulması ve geliştirilmesi temelli değerlendirmelere başlanmıştır. Üçüncü gelişme ise iletişimin ve gelişimin yaygınlaşması olmuştur (Schmitt, 1999b: 3). Söz konusu bu üç gelişme, pazarlama için yeni bir yaklaşımın işaretleri olarak gösterilmiştir.

\section{Deneyimsel Memnuniyet}

Fornell, müşteri memnuniyetini; müşterilerin ürün veya hizmetteki tüm satın alma deneyimlerine yönelik genel değerlendirme olduğunu belirtmektedir (You-Ming, 2010: 192). Genel satın alma deneyimi, müşterilerin memnuniyeti için ölçüm ve değerlendirme temelli bir gerekliliktir. Aslına bakılırsa memnuniyet deneyimlerde önemli bir değişken statüsündedir (Oliver, 1980, Oliver ve Westbrook, 1993, Ueacharoenkit, 2013: 48). Belirli bir işlemin müşteri memnuniyeti, satın alımdan hemen sonra gerçekleşen değerlendirme veya son işlem deneyimlerine karşı olumlu hislerdir (Oliver, 1993, Ueacharoenkit, 2013: 91). Müşterilerin kişisel deneyimleri, hizmet ilişkisi hakkında bilişsel ve etkili bir değerlendirme yapmak için kullanılmakta ve böylelikle de memnuniyet derecesi oluşturulmaktadır (Storbacka, Standvik ve Grönroos, 1994: 25). Pine ve Gilmore, müşteri memnuniyetinin müşterilerin ürün ile ilgili deneyimlerine dayanarak değerlendirildiğini ve büyük ölçüde müşterinin kalitenin beklentilerine göre, ürünle ilgili bireysel deneyimlerini değerlenmesine bağlı olduğunu belirtmişlerdir (2002). Deneyimsel memnuniyet hizmet memnuniyeti kavramından genişletilmiş olsa da aslında deneyimsel memnuniyet, tüketicilerin tüketimden sonraki deneyimlerinin genel değerlendirilmesine odaklanmaktadır (Kao, Huang ve Yang, 2007: 85). Bu bağlamda, deneyimsel bakış açısından deneyimsel memnuniyet; belirli bir işlemle ilişkili hizmet içeriğinden elde edilen memnuniyeti yansıtmaktadır (Kao, Huang ve $W u, 2008: 166$ ). Müşteriler, deneyimlerini önceki beklentileriyle karşılaştırmakta ve bunun neticesinde olumlu ya da olumsuz ayrışmaya neden olmaktadır. Olumlu-olumsuz etkilerden kaynaklanan duygusal tepkiler, müşteri memnuniyeti ya da memnuniyetsizliğinin temelini oluşturmaktadır (Bigne vd., 2005: 835).

\section{Tavsiye Etme Niyeti}

Bugünün tüketicileri kendileri gibi düşünen ve hareket eden sosyal çevrelerinden kendilerini etkileyen en doğru, en samimi, en yapıcı ve en çok deneyimlenmiş ürünleri veya hizmetleri satın alma eğilimindedirler (Batı, 2018: 117). Burada tüketicilerin yönlendirilmesi konusunda, aile ve arkadaşlarının bir ürün veya marka ile tecrübe ve tavsiyelerini önemsemektedirler. Tüketiciler bir hizmet sağlayıcısına sadık olduklarında, aldıkları bu hizmeti ailesine, arkadaşına veya yakın 
çevresi gibi diğer müşterilere önermekten memnuniyet duyarlar. Bu nedenle, müşterilerin tavsiye etme isteği sadakatin güçlü bir belirtisidir (Reichheld, 2003, Costa vd., 2017: 218). Suryawan (2013: 4), tüketici sadakatini ölçmede kullandıkları üç göstergeden birisi olan başkalarına tavsiye etme niyetini, tüketicilerin yaşadıkları olumlu deneyimlerin sonucu olarak ifade etmiştir. Ayrıca Kristensen, Martensen ve Gronholdt (2000: 1009) tarafından yapılan müşteri memnuniyeti ölçümü çalışmalarında ACSI (Amerikan Müşteri Memnuniyeti Endeksi; Fornell vd., 1996) modelinde müşteri sadakati ölçümünde üç değişkenden biri olan tavsiye etme niyetini incelenmişlerdir.

Prus ve Brant, müşteri memnuniyetinin müşteri sadakatini artırdığını belirterek müşteri sadakatini; bir marka veya işletme ile uzun vadeli bir ilişkiyi sürdürme taahhüdü ve aynı ürün veya hizmeti başkalarına tavsiye etme davranışı olarak ifade etmişlerdir (Rahim vd., 2012: 16). Bu nedenle bir ürün veya hizmet deneyimine sahip olan tüketicilerin, deneyimlerden memnun kaldıklarında ürünü veya hizmet deneyimini başkalarına tavsiye etme olasılıkları daha yüksektir.

Müşterilerin deneyimlerine odaklanan deneyimsel pazarlama, işletmeler için büyümenin ve sürdürülebilirliğin anahtarı, aynı zamanda da pazarlama inovasyonu niteliğindedir. Deneyim ekonomisine uyum sağlama aracı olan deneyimsel pazarlama, müşterilerine sunduğu eşsiz ve keyifli deneyimleri ile deneyimsel memnuniyeti oluşturmaktadır. Müşterilerin yaşadıkları deneyimlerden memnun olmaları sadakatlerinin güçlü bir göstergesi olan tavsiye eme niyetlerini yönlendirmektedir. Bu nedenle müşterilerin ürün veya hizmet sunum ortamlarında duygusal, duygusal, davranışsal, düşünsel ve ilişkisel deneyimlerinin deneyimsel memnuniyet ve tavsiye etme niyetlerindeki etki güçlerini Golf turizminde ampirik çalışmalarla belirlemek literatüre önemli katkılar sağlayacaktır.

\section{YÖNTEM}

Araştırmada nicel araştırma yöntemlerinden nedensel araştırma yöntemi kullanılmıştır. Bu çalışma 2016 yılında Samsun Büyükşehir Belediyesi tarafından yapılan ve Türkiye standartlarının üzerindeki altyapısıyla büyük ilgi gören, Karadeniz'in ilk modern Links Tipi golf sahasına sahip olan Samsun Golf Kulübün'de yürütülmüştür. Yüksek turizm potansiyeline sahip olan Samsun son dönemlerde yapılan yatırımlarla birlikte bir spor kenti olma yolunda emin adımlarla ilerlemektedir. Şöyle ki; buz sporları, plaj voleybolu, yelken, basketbol, su kayağı, yüzme ve okçuluk gibi tesislerin kısa sürede ulaşılabilir bir mesafede olması, aynı zamanda yeniden düzenlenen sahil bölgesi ve modern otelleri ile şehir bir cazibe merkezine dönüşmüştür.

\section{Araştırmanın Yöntemi ve Metodolojisi}

Araştırmada toplanan veriler anket yöntemini kullanılarak elde edilmiş birincil verilerdir. Bu çalışmada kolayda örneklem yöntemi kullanılmıştır. Araştırmada Samsun Golf Kulübü'nde golf oynayanlardan oluşan örnekleme anket uygulanarak veriler elde edilmiş ve araştırma modeli test edilmiştir. Araştırmada verinin toplanmasında kullanılan anket soruları, ulusal ve uluslararası literatürde araştırmacılar tarafından kullanılan ölçeklerden uyarlanarak tasarlanmıştır. Anket formu ile elde edilen bilgiler istatistik paket programları IBM SPSS 22 ve Smart PLS 3.0 kullanılarak analiz edilmiştir.

\section{Araştırmanın Modeli}

Hem ulusal hem de uluslararası literatür taraması sonucunda, araştırmaya ilişkin değişkenler: deneyimsel pazarlama boyutları (duyusal, duygusal, düşünsel, davranışsal ve ilişkisel) ile deneyimsel memnuniyet ve tavsiye etme niyetidir. 


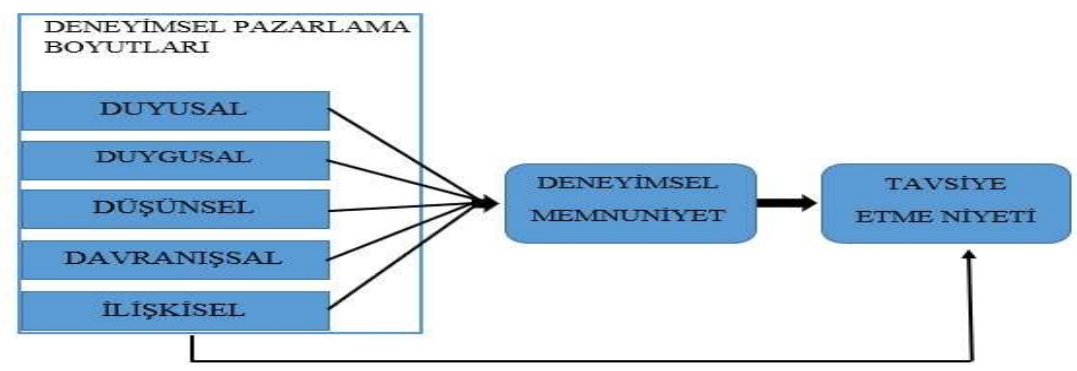

Şekil 1. Araştırmanın Modeli

Kao, Huang ve Yang (2007), çalışmalarında daha yüksek duygusal deneyimler daha yüksek deneyimsel tutum ve deneyimsel memnuniyete yol açtığını belirlemişlerdir. Aynı çalışmada deneyimsel bir tutumun, deneyimsel memnuniyetle pozitif ilişkide olduğu belirtilmiştir. Tüketicilerin deneyimlerden daha çok memnun olduklarında, tekrar alım ve tavsiye niyetleriyle ifade edilen daha yüksek sadakat niyetleri sergileme olasılıklarının daha yüksek olduğu ve daha yüksek tekrar alım niyetinin daha yüksek öneri niyetine yol açacağı sonucuna varılmıştır.

Akyıldız (2010), 2009 Rock'n Coke Festivali'ne katılan bireylerin boş zaman deneyimlerinin incelemesi amaçlı bir çalışma yürütmüştür. Araştırmadan elde edilen sonuçlara göre, boş zaman katılımcılarının festivale katılım sonrasında edinmiş olduğu deneyimlerinin, tavsiye etme niyeti ve memnuniyet durumu üzerinde olumlu bir etkiye sahip olduğu belirlenmiştir. Ayrıca katılımcıların memnuniyet durumlarının tavsiye etme niyetini etkilediği ortaya çıkmıştır.

Deligöz (2014), Ankara merkezde bulunan Starbucks ve Kahve Dünyasının tüketicileri ile yapmış olduğu çalışmasında, deneyimsel pazarlama boyutlarının tüketiciler tarafından nasıl algılandığını ve deneyimsel memnuniyet ile bağlllık üzerindeki etkilerini ölçmeyi amaçlamıştır. Araştırmanın sonuçlarına göre, deneyimsel pazarlama boyutlarının tümünün deneyimsel memnuniyet ve bağl1lık üzerinde etkisinin olduğu ortaya çıkmıştır. Ayrıca Starbucks müşterileri için, deneyimsel pazarlama boyutlarından duygusal, davranışsal ve ilişkisel deneyimlerin Kahve Dünyası müşterilerine oranla daha çok tatmin edici olduğu ve bu deneyim boyutlarının deneyimsel memnuniyet ile deneyimsel bağllı̆̆a olan etki düzeylerinin daha yüksek olduğu belirlenmiştir.

Başar (2015), İstanbul ilinde Panorama 1453 Tarih Müzesi ziyaretçileriyle yaptığı çalışmada, deneyimsel pazarlama hizmetleri sonucu kültürel ve sanatsal etkinliklere katılan ziyaretçilerin sadakatlerini belirlenmeyi hedeflemektedir. Çalışma bulgularına göre, deneyim boyutlarından duyusal, davranışsal ve sosyal boyutların müşteri tatmini üzerinde etkisi olmazken, duygusal ve düşünsel boyutlarda etkisinin olduğu ortaya çıkmıştır. Ayrıca ziyaretçilerin tatmin seviyesinin, müzeyi tekrar ziyaret etme niyetini olumlu etkilediği tespit edilmiştir. Diğer taraftan, önemli göstergelerden biri olan tekrar ziyaret etme niyeti ziyaretçilerin sadakatini olumlu yönde etkilerde bulunmuştur. Bunların yanı sıra, ziyaretçilerin müzeden memnun olma seviyelerinin müşteri sadakati üzerinde olumlu etkilerinin olduğu bulunmuştur.

Aracı (2016), İzmir' in birinci sınıf yiyecek ve içecek restoranlarındaki örnek grup ile deneyimsel pazarlamanın, müşteri memnuniyetini ve davranışsal niyeti oluşturan temel boyutlar arasındaki ilişkileri incelemiştir. Sonuçlar genel olarak, deneyimsel pazarlama boyutlarından duygusal ve ilişkisel deneyimin hem müşteri memnuniyetini hem de davranışsal niyeti etkileyen boyutlar olduğunu belirtmektedir. Müşteri memnuniyeti ise davranışsal niyeti oluşturan geri alım, tavsiye etme niyeti ve daha fazla ödeme yapma boyutlarında etkili olmuştur. Ayrıca müşteri memnuniyetinin, bazı deneyimsel pazarlama ve davranışsal niyet boyutları arasında bir aracı değişken olarak hareket ettiği belirlenmiştir. 


\section{Araştırma Hipotezleri}

Araştırmanın amacına ve modeline ilişkin geliştirilmiş hipotezler aşağıda sıralanmıştır:

H1: Oyuncuların yaşadıkları duyusal deneyimler deneyimsel memnuniyeti anlamlı ve pozitif yönde etkilemektedir.

H2: Oyuncuların yaşadıkları duygusal deneyimler deneyimsel memnuniyeti anlamlı ve pozitif yönde etkilemektedir.

H3: Oyuncuların yaşadıkları düşünsel deneyimler deneyimsel memnuniyeti anlamlı ve pozitif yönde etkilemektedir.

H4: Oyuncuların yaşadıkları davranışsal deneyimler deneyimsel memnuniyeti anlamlı ve pozitif yönde etkilemektedir.

H5: Oyuncuların yaşadıkları ilişkisel deneyimler deneyimsel memnuniyeti anlamlı ve pozitif yönde etkilemektedir.

H6: Oyucuların yaşadıkları duyusal deneyimler tavsiye etme niyetini anlamlı ve pozitif yönde etkilemektedir.

H7: Oyucuların yaşadıkları duygusal deneyimler tavsiye etme niyetini anlamlı ve pozitif yönde etkilemektedir.

H8: Oyucuların yaşadıkları düşünsel deneyimler tavsiye etme niyetini anlamlı ve pozitif yönde etkilemektedir.

H9: Oyucuların yaşadıkları davranışsal deneyimler tavsiye etme niyetini anlamlı ve pozitif yönde etkilemektedir.

H10: Oyucuların yaşadıkları ilişkisel deneyimler tavsiye etme niyetini anlamlı ve pozitif yönde etkilemektedir.

H11: Deneyimsel memnuniyet tavsiye etme niyetini anlamlı ve pozitif yönde etkilemektedir.

H12: Oyuncuların yaşadıkları duyusal deneyimler deneyimsel memnuniyet üzerinden tavsiye etme niyetini dolaylı olarak etkilemektedir.

H13: Oyuncuların yaşadıkları duygusal deneyimler deneyimsel memnuniyet üzerinden tavsiye etme niyetini dolaylı olarak etkilemektedir.

H14: Oyuncuların yaşadıkları düşünsel deneyimler deneyimsel memnuniyet üzerinden tavsiye etme niyetini dolaylı olarak etkilemektedir.

H15: Oyuncuların yaşadıkları davranışsal deneyimler deneyimsel memnuniyet üzerinden tavsiye etme niyetini dolaylı olarak etkilemektedir.

H16: Oyuncuların yaşadıkları ilişkisel deneyimler deneyimsel memnuniyet üzerinden tavsiye etme niyetini dolaylı olarak etkilemektedir.

\section{Araştırmanın Evreni, Örneklem ve Veri Toplama Yöntemi}

Araştırmanın evrenini, Samsun ilinde bulunan Samsun Golf Kulübü'nden hizmet alan golf oyuncuları oluşturmaktadır. Araştırma verileri kolayda örneklem yöntemi ile Samsun Golf Kulübü oyuncularından anket yolu ile toplanmıştır. Araştırma evreni 200 kişiden oluşmaktadır. Gol oyuncularının 90 kişisi 18 yaş altı bireylerdir (Gürkan, 2019: 30). Oluşturulan anket formu 18 yaş ve üstü golf oynayan oyuncular üzerinde uygulanmıştır. Toplam 90 anket uygulanmış, hatalı ve eksik cevaplandırılan anketler elendikten sonra toplam 85 kullanılabilir anket değerlemeye 
tabi tutulmuştur. Anketler yüz yüze görüşme yoluyla 15 Mart- 20 Temmuz 2019 tarihleri arasında yapılmıştır. Araştırma anketi 3 kısımdan oluşmaktadır. İlk kısım sorular, oyuncuların deneyimsel pazarlama boyutlarına yönelik tutumlarını, ikinci kısım sorular deneyimsel memnuniyetlerini ve tavsiye etme niyetleri, üçüncü kısım sorular ise demografik özellikleri tespit etme amacıyla hazırlanmıştır. Ankette yer alan sorular: "1: Kesinlikle Katılmıyorum ile 5: Kesinlikle Katılıyorum" arasında değişen 5’li Likert ölçeğine göre tasarlanmıştır. Bu çalışmada deneyimsel pazarlama boyutları değişkenleri için kullanılan ölçekler Brakus, Schmitt ve Zarantonello (2009), Schmitt (1999b), Kao vd., (2008), Günay (2009), Deligöz (2014), Yang (2009), McAlexander vd., (2002), Erbaş (2010) ve Ünal vd., (2014), tarafından geliştirilmiştir. Deneyimsel memnuniyet ve tavsiye etme niyeti için kullanılan ölçekler ise Chang ve Chieng (2006), Kao vd., (2008), Yuan ve $\mathrm{Wu}$ (2008) ve Baloglu (2002) tarafından geliştirilmiştir.

\section{BULGULAR}

Bu bölümde öncelikle katılımcıların tanımlayıcı bilgileri ortaya konmuştur. Sonraki aşamada araştırma modelinde yer alan faktörlere ilişkin tanımlayıcı istatistikler ve hipotez testlerine ait bulgularına yer verilmiştir.

\section{Katılımcıların Tanımlayıcı Bilgileri}

Araştırmaya katılanların demografik özelliklerine ilişkin bilgiler Tablo 1'de gösterilmiştir.

Tablo 1. Katılıcıların Demografik Özelliklerinin Dağılımı

\begin{tabular}{|c|c|c|c|c|c|c|c|}
\hline & $\begin{array}{l}\text { Demografik } \\
\text { Özellikler }\end{array}$ & $\mathrm{f}$ & $\%$ & & $\begin{array}{l}\text { Demografik } \\
\text { Özellikler }\end{array}$ & $\mathbf{f}$ & $\%$ \\
\hline \multirow{2}{*}{ 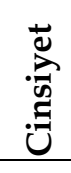 } & Kadın & 31 & 36,5 & \multirow{2}{*}{ 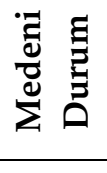 } & Evli & 52 & 61,2 \\
\hline & Erkek & 54 & 63,5 & & Bekâr & 33 & 38,8 \\
\hline \multirow{5}{*}{ 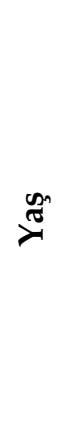 } & $18-25$ & 14 & 6,5 & \multirow{4}{*}{ 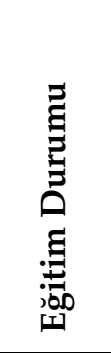 } & Ortaöğretim & 3 & 3,5 \\
\hline & $26-33$ & 14 & 16,5 & & Ön Lisans & 9 & 10,6 \\
\hline & $34-41$ & 25 & 29,4 & & Lisans & 40 & 47,1 \\
\hline & $42-49$ & 28 & 32,9 & & Lisansüstü & 33 & 38,8 \\
\hline & $50-57$ & 4 & 4,7 & \multirow{5}{*}{ 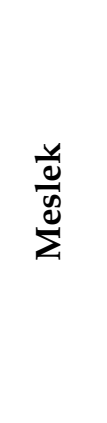 } & Memur & 29 & 34,1 \\
\hline \multirow{4}{*}{ 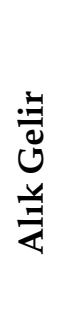 } & $2.000 € ’ y e$ kadar & 6 & 7,1 & & Serbest Ms. & 6 & 7,1 \\
\hline & $2.001-3.500 €$ & 9 & 10,6 & & Emekli & 1 & 1,2 \\
\hline & $3.501-5000 €$ & 16 & 18,8 & & Öğrenci & 6 & 7,1 \\
\hline & 5001 € ve üstü & 54 & 63,5 & & Özel Sektör & 43 & 50,6 \\
\hline
\end{tabular}


Katılımcıların \%63,5'i ise erkek, \%32,9'u 42-49 yaş aralığında, \%61,2'si evli ve \% 47,1'i lisans mezunudur. Ayrıca \% 63,5'i 5.001 TL ve üzeri gelir düzeyine sahiptir ve \% 50,6'sı özel sektörde çalışmaktadır.

Tablo 2'de ise katılımcların kulüp üyelikleri, golf oynama süreleri ve Samsun Golf Kulübünden aldıkları hizmet süresine ilişkin bilgiler yer almaktadır.

Tablo 2. Katılıcıların Golf ve Samsun Golf Kulübüne Yönelik Frekans Değerleri

\begin{tabular}{lcc}
\hline & f & $\%$ \\
\hline Kulüp Üyeliğiniz Varmı? & 20 & \\
\hline Evet & 65 & 23,5 \\
\hline Hayır & & 76,5 \\
\hline Kaç yıldır golf oynuyorsunuz? & 75 & 88,2 \\
\hline 1-3 yıl & 3 & 3,5 \\
\hline 4-6 yıl & 2 & 2,4 \\
\hline 7-9 yıl & 5 & 5,9 \\
\hline 10+ yıl & & \\
\hline Kaç Y1ldır Bu Kulüpten Hizmet Alıyorsunuz? & 44 & 51,8 \\
\hline 1 yıldan az & 38 & 44,7 \\
\hline 2-3 yıl & 3 & 3,5 \\
\hline 3+ yıl
\end{tabular}

Tabloya bakıldığında katılımcıların \%76,5'nin Samsun Golf Kulübüne üye olmadıkları görülmektedir. Ayrıca \% 88,2'si 1-3 yıldır golf oynadığı ve \% 51,8'inin bir yıldan az bir sürede kulüpten hizmet aldıkları belirlenmiştir.

Tablo 1 ve $2^{\prime}$ den de görüldüğü üzere araştırmaya katılan katılımcıların sayısı $n=85^{\prime}$ tir. Bu örneklem grubu sayısı, Hair vd., (2013) tarafından önerilen (en az 0,25 değerinde R-kare değerleri elde edilirken \%80'lik bir istatistiksel güç elde etmek için minimum 59 gözlemin gerekli olduğu) asgari örneklem büyüklük ilkesini sağlamaktadır (Thompson, Barclay ve Higgins, 1995). Aynı zamanda bu örneklem sayısı Olya (2017) tarafından önerilen örneklem büyüklügü̈ (minimum 30100) şartını sağlamaktadır (Chin ve Newsted, 1999). Bir diğer önemli husus, PLS yol modelinde herhangi bir gizil değişkeni işaret eden maksimum ok sayısının "en az 10 katı" ile çarpılarak model için gerekli asgari gözlem sayısının hesaplanmasıdır ki bu kural "en az 10 katı kuralı" olarak ifade edilmektedir (Hair vd., 2014). Bu kural çerçevesinde araştırma modelinde herhangi bir gizil değişkeni işaret eden maksimum ok sayısı $6^{\prime}$ dır. Yine bu kurala istinaden $6^{*} 10=60$ PLS yol modelini tahmin etmede gereken asgari örneklem sayısını karşılamış olmaktadır.

\section{Cevaplayıcıların Deneyimsel Pazarlama, Deneyimsel Memnuniyet ve Tavsiye Etme Niyeti Değişkenlerine Yönelik Değerlendirmeleri}

Araştırmada kullanılan deneyimsel pazarlama boyutlarının ölçek ifadelerine ilişkin ortalama ve standart sapma değerleri sırasıyla Tablo 3'te verilmiştir. Araştırmada kullanılan deneyimsel memnuniyet ve tavsiye etme niyeti ölçeklerine yönelik ortalama ve standart sapma değerleri Tablo $4^{\prime}$ te verilmiştir. 
Tablo 3. Deneyimsel Pazarlama Boyutları Değişkenlerine Ait İstatistikler DUYUSAL DENEYIM (DUYD) Aritmetik Ort. (AO) $=4,35$, Standart Sapma (SS) $=0,64$

$\mathrm{AO}^{*} \quad \mathrm{SS}$

S1. Bu kulüp görsel duyum ve diğer duyularım üzerinde güçlü etkiler birakır.

\begin{tabular}{lcc} 
S2. Bu kulübü duyusal açıdan ilgi çekici buluyorum. & 4,33 &, 79 \\
\hline S3. Bu kulüp duyularıma hitap etmez. S3 & 4,34 &, 72 \\
\hline DUYGUSAL DENEYIM (DUYGD) AO= 4,28 SS=0,52 & AO $^{*}$ & SS \\
\hline
\end{tabular}

$\begin{array}{lll}\text { S4. Bu kulüp çalışanları güler yüzlü ve cana yakındır. } & 4,52 & \text {,64 }\end{array}$

S5. Bu kulüpte kendimi rahatlamış ve mutlu hissediyorum. $\quad 4,61 \quad$,61

S6. Bu kulübün konforlu ve samimi bir ortam sapladığını düşünüyorum.

S7. Bu kulüpte keyifli vakit geçiriyorum. $\quad 4,36 \quad 78$

S8. Bu kulüpte ürünlerin, çalışanların, dekorasyonun bir bütün olarak $\quad 4,15 \quad$,89 sağladıkları atmosfer duygularıma hitap eder.

S9. Bu kulüpte golf oynamak eğlencelidir. $\quad 4,63 \quad, 59$

$\begin{array}{lll}\text { S10. Bu kulüp duygusal kulüptür. } & 3,77 & \text { 92 }\end{array}$

DÜŞÜNSEL DENEYIM (DÜŞD) AO= 3,71 SS=0,74 $\quad$ AO $^{*} \quad$ SS

S11. Bu kulüp benim yaratıcı düşünmeme yardımcı oluyor. $\quad 3,97 \quad$, 11

S12. Bu kulübün günlük gelişmeleri takip edebileceğim basılı ve görsel $\quad 3,65 \quad 1,1$ mecralar ile internet bağlantısı var.

S13. Bu kulüpte düşünmek için rahat ortam var.

S14. Bu kulüp ile ilgili son gelişmeleri kulübün internet sayfasından

$4,21 \quad, 76$

$3,01 \quad 1,2$

takip ederim.

\begin{tabular}{|c|c|c|}
\hline DAVRANIŞSAL DENEYİM (DAVD) AO= $3,98 \mathrm{SS}=0,71$ & $\mathrm{AO}^{*}$ & SS \\
\hline $\begin{array}{l}\text { S15. Bu kulüp ev, okul ya da iş yerleri dışında sosyalleşebileceğim, vakit } \\
\text { geçirebileceğim güzel mekandır. }\end{array}$ & 4,51 & 66 \\
\hline $\begin{array}{l}\text { S16. Bu kulüpte bilgi düzeyimi artırıcı materyallerin bulunması hoşuma } \\
\text { gidiyor. }\end{array}$ & 3,88 & 1,1 \\
\hline S17. Bu kulübün hizmet anlayışını beğeniyorum. & 4,19 & ,79 \\
\hline $\begin{array}{l}\text { S18. Bu kulübü ziyaret etmek yaşam biçimimi değiştirdi ve hayatımın bir } \\
\text { parçası haline geldi. }\end{array}$ & 3,81 & 1,1 \\
\hline S19. Bu kulübün internet kullanma imkânlarından hoşlanıyorum. & 3,52 & 1,2 \\
\hline İLIŞKİSEL DENEYIM (İLIŞD) AO= 3,62 SS=0,91 & $\mathrm{AO}^{*}$ & SS \\
\hline S20. Bu kulüp sosyal çevremin gelişmesine yardımcı olur. & 4,17 & ,88 \\
\hline $\begin{array}{l}\text { S21. Bu kulüp ile sosyal medyada (basında) çıkan haberleri takip } \\
\text { ederim. }\end{array}$ & 3,46 & 1,2 \\
\hline S22. Bu kulübün paydaşı/hissedarı olmak isterim. & 3,23 & 1,3 \\
\hline
\end{tabular}

*5: Kesinlikle katıliyorum..........1: Kesinlikle katılmıyorum 
Katılımcıların duyusal deneyim ölçeğine ilişkin verdikleri cevapların ortalaması 4,33 ile 4,39 arasında değişmektedir. Cevaplayıcıların en az katıldıkları ifade “Bu kulübü duyusal açıdan ilgi çekici buluyorum", en çok katıldıkları ifade ise "Bu kulüp görsel duyum ve diğer duyularım üzerinde güçlü etkiler bırakır" ifadesidir. Duygusal deneyim ölçeğinin ifadelerine ilişkin verilmiş cevapların ortalamaları 3,77 ile 4,63 arasında değişmektedir. Katılımcıların bu ölçekte en az katıldıkları ifade "Bu kulüp duygusal kulüptür" en çok katıldıkları ifade ise "Bu kulüpte golf oynamak eğlencelidir" ifadesi olmuştur.

Katılımcların düşünsel deneyim ölçeğine ilişkin vermiş olduğu ifadelerin ortalamaları 3,01 ile 4,21 arasında değişmektedir. Katılımcıların en az katıldıkları ifade "Bu ile ilgili son gelişmeleri kulübün internet sayfasından takip ederim", en çok katıldıkları ifade ise "Bu kulüpte düşünmek için rahat ortam var" ifadesi olmuştur. Davranışsal deneyim ölçeğinin ifadelerine ilişkin verilmiş cevapların ortalamaları 3,80 ile 4,51 arasında değişmektedir. Katılımcıların bu ölçekte en az katıldıkları ifade "Bu kulübü ziyaret etmek yaşam biçimimi değiştirdi ve hayatımın bir parçası haline geldi", en çok katıldıkları ifade ise "Bu kulüp ev, okul ya da iş yerleri dışında sosyalleşebileceğim, vakit geçirebileceğim güzel mekândır." ifadesi olmuştur. Katılımcıların ilişkisel deneyim ölçeğine ilişkin vermiş olduğu ifadelerin ortalamaları 3,23 ile 4,17 arasında değişmektedir. Katılımcıların en az katıldıkları ifade "Bu kulübün paydaşı/hissedarı olmak isterim", en çok katıldıkları ifade ise "Bu kulüp sosyal çevremin gelişmesine yardımcı olur" ifadesi olmuştur.

Deneyimsel memnuniyetin genel ortalaması 4,36 olup, katılımcıların en az katıldıkları ifade "Bu golf kulübü benim beklentilerimin çok üzerindedir", en çok katıldıkları ifade ise "Bu golf kulübünde geçirdiğim zamanın çok iyi geçirilmiş zaman dilimi olduğunu söyleyebilirim" ifadesidir. Tavsiye etme niyetinin genel ortalaması 4,53 olup, katılımcların en az katıldıkları ifade "Başkalarına bu kulüpte golf oynadığımı söylemekten gurur duyuyorum", en çok katıldıkları ifade ise "Bu kulübü arkadaşlarıma da tavsiye ederim" ifadesi olmuştur.

Tablo 4. Deneyimsel Memnuniyet ve Tavsiye Etme Niyeti Değişkenine Ait İstatistikler

\begin{tabular}{lcc}
\hline DENEYIMSEL MEMNUNIYET (DENM) AO= 4,36 SS=0,53 & AO* & SS \\
\hline S23. Bu golf kulübünden çok iyi hizmet alıyorum. & 4,31 &, 67 \\
\hline S24. Bu golf kulübü benim golf oynama ve sosyalleşme ihtiyacımı karşılıyor. & 4,46 &, 64 \\
\hline S25. Bu golf kulübü benim beklentilerimin çok üzerindedir. & 4,00 & 1,1 \\
\hline S26. Bu golf kulübünü her ziyaretimde çok keyif alıyorum. & 4,47 &, 64 \\
\hline $\begin{array}{l}\text { S27. Bu golf kulübünde geçirdiğim zamanın çok iyi geçirilmiş zaman dilimi } \\
\text { olduğunu söyleyebilirim. }\end{array}$ & 4,48 &, 59 \\
\hline S28. Bu golf kulübünü gerçekten çok seviyorum. & 4,45 &, 63 \\
\hline TAVSIYYE ETME NiYYETI (TAV) AO=4,53 SS=0,54 & AO* & SS \\
\hline S29. İnsanlara bu kulüp hakkında olumlu şeyler söylerim. & 4,54 &, 71 \\
\hline S30. Bu kulüp hakkında söylenecek çok şey var. & 4,51 &, 68 \\
\hline S31. Başkalarına bu kulüpte golf oynadığımı söylemekten gurur duyuyorum. & 4,41 &, 71 \\
\hline S32. Bu kulübü arkadaşlarıma da tavsiye ederim. & 4,66 &, 49 \\
\hline
\end{tabular}

* 5: Kesinlikle katıliyorum...........1: Kesinlikle katılmıorum 


\section{Araştırma Modelinin Analizi}

Literatür araştırması sonucunda oluşturulan araştırma modelinin analizi için, PLS-SEM (Kısmi En Küçük Kareler Yapısal Eşitlik Modellemesi) yöntemi ile SmartPls 3.0 paket programı kullanılmıştır. PLS-SEM gizil değişkenler ve onların ilişkileri ile gizil yol modellerini tahmin etmektedir. PLS Yol Modellemesi, işletme ve sosyal bilimlerde yaygın olarak uygulanan varyansa dayalı yapısal denklem modelleme (SEM) tekniğidir (Hair vd., 2017). PLS-SEM süreci sonuçlarının analiz edilmesi ve yorumlanmasında Wong'un (2013) önermiş olduğu yol dikkate alınmıştır. İki aşamalı olarak analiz edilen PLS-SEM modellemesinin ilk aşaması, ölçüm modelidir (dış model olarak da adlandırılır). Ölçüm modeli, gizil değişkenler ve bunların gözlenen göstergeleri arasındaki ilişkileri belirlemektedir. Ölçüm modelindeki değişkenlerin geçerlik ve güvenirlilik değerleri Tablo 5 'te verilmiştir. İkinci aşama ise yapısal modeldir (iç model olarak da adlandırılır). Yapısal model, bağımsız ve bağımlı gizil değişkenler arasındaki ilişkileri belirlemektedir. Buna göre yapısal model test edilmiş ve elde edilen bulgular paylaşılmıştır.

\section{Ölçüm Modelinin Geçerliliği ve Güvenirliliği}

Araştırmanın ölçüm modelinin geçerliliği ve güvenilirliğinin değerlendirilmesinde Wong (2013)'un çalışmaları kapsamında SmartPLS 3.0 paket programı üzerinden elde edilmiş yakınsama geçerlilik değerleri sırasıyla; gösterge yükleri, bütünleşik güvenirlik (CR), cronbach alfa (CA), ortalama açıklanan varyans (AVE) değerleridir ve bu değerler Tablo 5 'te gösterilmiştir. Ayrıştırma geçerliliği için önerilen Fornell-Larcker ve Gizil Değişken Korelasyon Değerleri kullanılmış ve Tablo 6'da gösterilmiştir. Araştırmanın ölçüm modelinin geçerliliği ve güvenilirliğinin değerlendirilmesinde. Tablo 5'te paylaşılan değerler daha yakından incelendiğinde araştırmada toplam yedi gizil değişkenin olduğu görülmektedir. Gizil değişkenlere ait gösterge değerlerinin faktör yük aralıkları duyusal deneyim için ,68 ile, 90; duygusal deneyim için ,59 ile, 82; davranışsal deneyim için ,56 ile ,83; düşünsel deneyim için, 63 ile ,88; ilişkisel deneyim için ,49 ile ,92; deneyimsel memnuniyet için ,79 ile ,91; tavsiye etme niyeti için ise 77 ile, 87 aralığında farklı değerler almıştır. Bununla birlikte gösterge yüklerinden literatürde kabul gören 0,40 altında kalan S10, S14, S19 ve S28 gizil değişkenleri araştırmanın geçerliliği ve güvenirliğinin sağlanması için modelden çıkarılmıştır (Hulland, 1999). Tablo 5 'te görüldüğü üzere, gösterge güvenilirliği için gözlenen gösterge yükleri gerekli olan geçerliliği sağlamıştır. Araştırmanın ölçüm modelinin içsel tutarlılık güvenirliliğinin değerlendirilmesinde Cronbach Alfa katsayılarına bakılmıştır. Tablo 5'te görüldüğü üzere $\alpha$ katsayıları ölçeklerin güvenir olarak kabul edilmesi için gerekli olan 0, 60'ın üstünde değerler almıştır (Hair vd., 2014; Afthanorhan, 2013; Olya, 2017). Ayrıca ölçüm modeline ait bütünleşik değerlerin güvenilir kabul edilebilmesi için literatür de kabul gören 0,60 veya 0,70 'in üzerinde olması şartının sağlandığı Tablo 5'te de görülmektedir (Bagozzi ve Yi, 1998; Olya, 2017). Ölçüm modelinin geçerliliğinin test edilmesinde ilk olarak AVE değerlerine bakılmalıdır. Tablo 5'te görüldüğü üzere AVE değerleri genel literatür de kabul gören 0,50 sınırı üzerinde değerler almış ve yakınsama geçerlilikleri doğrulanmıştır (Bagozzi ve Yi, 1998; Olya, 2017). Araştırmada ölçüm modelinin geçerliliğinin sağlanmasında diğer kriterler Fornell-Larcker değerlerine ve gizil değişkenler arasındaki korelasyon değerlerine bakılmaktır (Polat, 2018: 5331). Bu kriterlere ilişkin değerler Tablo 6'da gösterilmiştir. Tablo 6'da ölçüm modelinin Fornell-Larcker değerleri (koyu siyah renkli olarak) .728 ile .840 aralığında değişmekteyken korelasyon değerleri ise .368 ile .820 aralığında yer aldığı görülmektedir. Fornell ve Larcker (1981) kriterine göre, ölçüm modelinde kullanılan her bir gizil değişkenin AVE değerlerinin karekökünün, bulundukları sütunlardaki korelasyon değerlerinden daha büyük olması gerekmektedir. Tablo 6'da görülen ayrışma geçerliliği için bu kriterler sağlanmıştır. Modeli ait geçerlilik ve güvenilirlik değerlerin 
sağlanmasıyla ölçüm modelinin doğrulayıcı faktör analizi istenen kriterlere sahip olduğu görülmüştür.

Tablo 5. Ölçüm Modeline İlişkin Araştırma Geçerlilik ve Güvenirlilik Değerleri

\begin{tabular}{|c|c|c|c|c|c|}
\hline & Göstergeler & Gösterge Yükleri & $(\alpha)$ & CR & AVE \\
\hline \multirow{3}{*}{ DUYD } & S1 & 0,687 & \multirow{3}{*}{0,739} & \multirow{3}{*}{0,847} & \multirow{3}{*}{0,651} \\
\hline & S2 & 0,902 & & & \\
\hline & S3 & 0,817 & & & \\
\hline \multirow{6}{*}{ DUYGD } & S4 & 0,784 & \multirow{6}{*}{0,850} & \multirow{6}{*}{0,889} & \multirow{6}{*}{0,573} \\
\hline & S5 & 0,820 & & & \\
\hline & S6 & 0,749 & & & \\
\hline & S7 & 0,820 & & & \\
\hline & S8 & 0,599 & & & \\
\hline & S9 & 0,748 & & & \\
\hline \multirow{4}{*}{ DAVD } & S11 & 0,769 & \multirow{4}{*}{0,720} & \multirow{4}{*}{0,821} & \multirow{4}{*}{0,539} \\
\hline & $\mathrm{S} 12$ & 0,721 & & & \\
\hline & $\mathrm{S} 13$ & 0,857 & & & \\
\hline & S15 & 0,559 & & & \\
\hline \multirow{3}{*}{ DÜŞD } & S16 & 0,768 & \multirow{3}{*}{0,685} & \multirow{3}{*}{0,826} & \multirow{3}{*}{0,598} \\
\hline & S17 & 0,645 & & & \\
\hline & S18 & 0,888 & & & \\
\hline \multirow{3}{*}{ İLİŞD } & $\mathrm{S} 20$ & 0,931 & \multirow{3}{*}{0,648} & \multirow{3}{*}{0,760} & \multirow{3}{*}{0,530} \\
\hline & S21 & 0,694 & & & \\
\hline & S22 & 0,490 & & & \\
\hline \multirow{5}{*}{ DENM } & S23 & 0,838 & \multirow{5}{*}{0,856} & \multirow{5}{*}{0,897} & \multirow{5}{*}{0,635} \\
\hline & S24 & 0,858 & & & \\
\hline & S25 & 0,705 & & & \\
\hline & S26 & 0,790 & & & \\
\hline & S27 & 0,785 & & & \\
\hline \multirow{4}{*}{ TAV } & S29 & 0,773 & \multirow{4}{*}{0,859} & \multirow{4}{*}{0,905} & \multirow{4}{*}{0,705} \\
\hline & S30 & 0,884 & & & \\
\hline & S31 & 0,823 & & & \\
\hline & S32 & 0,874 & & & \\
\hline
\end{tabular}

Tablo 6. Ölçüm Modeline ait Fornell-Larcker ve Gizil Değişken Korelasyon Değerleri

\begin{tabular}{|l|c|c|c|c|c|c|c|}
\hline & DAVD & DUYG & TAV & ILIŞD & DENM & DUYD & DÜŞD \\
\hline DAVD & $\mathbf{0 , 7 3 4}$ & & & & & & \\
\hline DUYG & 0,678 & $\mathbf{0 , 7 5 7}$ & & & & & \\
\hline TAV & 0,642 & 0,729 & $\mathbf{0 , 8 4 0}$ & & & & \\
\hline İL̇ŞD & 0,526 & 0,564 & 0,368 & $\mathbf{0 , 7 2 8}$ & & & \\
\hline DENM & 0,686 & 0,658 & 0,820 & 0,450 & $\mathbf{0 , 7 9 7}$ & & \\
\hline DUYD & 0,537 & 0,658 & 0,555 & 0,412 & 0,491 & $\mathbf{0 , 8 0 7}$ & \\
\hline DÜŞD & 0,692 & 0,575 & 0,471 & 0,616 & 0,530 & 0,449 & $\mathbf{0 , 7 7 4}$ \\
\hline
\end{tabular}




\section{Yapisal Model}

Ölçüm modelinin geçerlilik ve güvenirlik testlerinin kabul görmesiyle, araştırmanın yapısal eşitlik analizini yapmak üzere yine SmartPLS 3.0 paket programı kullanılmış ve analiz sonrası yapısal modele ait sonuçlar Şekil $3^{\prime}$ te gösterilmiştir. PLS-SEM yönteminde içsel modelin değerlendirilmesinde modelin açıklayıcı gücünü ölçmek için determinasyon katsayısı olan $\mathrm{R}^{2}$ değeri kullanılmaktadır. $R^{2}$ değeri 0 ile 1 değeri arasında değer almakta ve tüketici davranışlarıyla ilgili bilimsel araştırmalarda 0,20; genelde ise 0,25 (düşük), 0,50 (orta) ve 0,50 (yüksek) değerleri kabul görmektedir (Hair vd., 2014). Şekil 13'te görüleceği üzere araştırma modelinde en yüksek $\mathrm{R}^{2}$ değeri tavsiye etme niyeti değişkeninde görülmektedir. Tavsiye etme niyetinin \% $75^{\prime} \mathrm{i}$ $\left(\mathrm{R}^{2}=0,756\right)$ duyusal deneyim, duygusal deneyim, davranışsal deneyim, düşünsel deneyim, ilişkisel deneyim ve deneyimsel memnuniyet tarafından açılanmaktadır. Diğer $\mathrm{R}^{2}$ değeri deneyimsel memnuniyet değişkenine aittir. Deneyimsel memnuniyetin \% 53'i $(0,537)$ duyusal deneyim, duygusal deneyim, davranışsal deneyim, düşünsel deneyim ve ilişkisel deneyim tarafından açıklanmıştır. Araştırma modelinin tahmin gücünü ölçmek için $\mathrm{Q}^{2}$ değeri kullanılmıştır. Bu değerin elde edilmesinde programda Blindfolding yöntemi çalıştırılmıştır. Bu yöntemle elde edilen bilgilerle, kurgulanan modelde deneyimsel memnuniyet için $\mathrm{Q}^{2}=0.227$ iken tavsiye etme niyeti için ise $\mathrm{Q}^{2}=0.476$ olarak hesaplanmıştır. Elde edilen $\mathrm{Q}^{2}$ değerlerin sıfırdan büyük olma şartını sağlamıştır (Hair vd., 2014). Dolaylısıyla araştırma modelinin deneyimsel memnuniyet ve tavsiye etme niyeti değişkenlerini tahmin etme gücüne sahip oldukları ifade edilebilir.

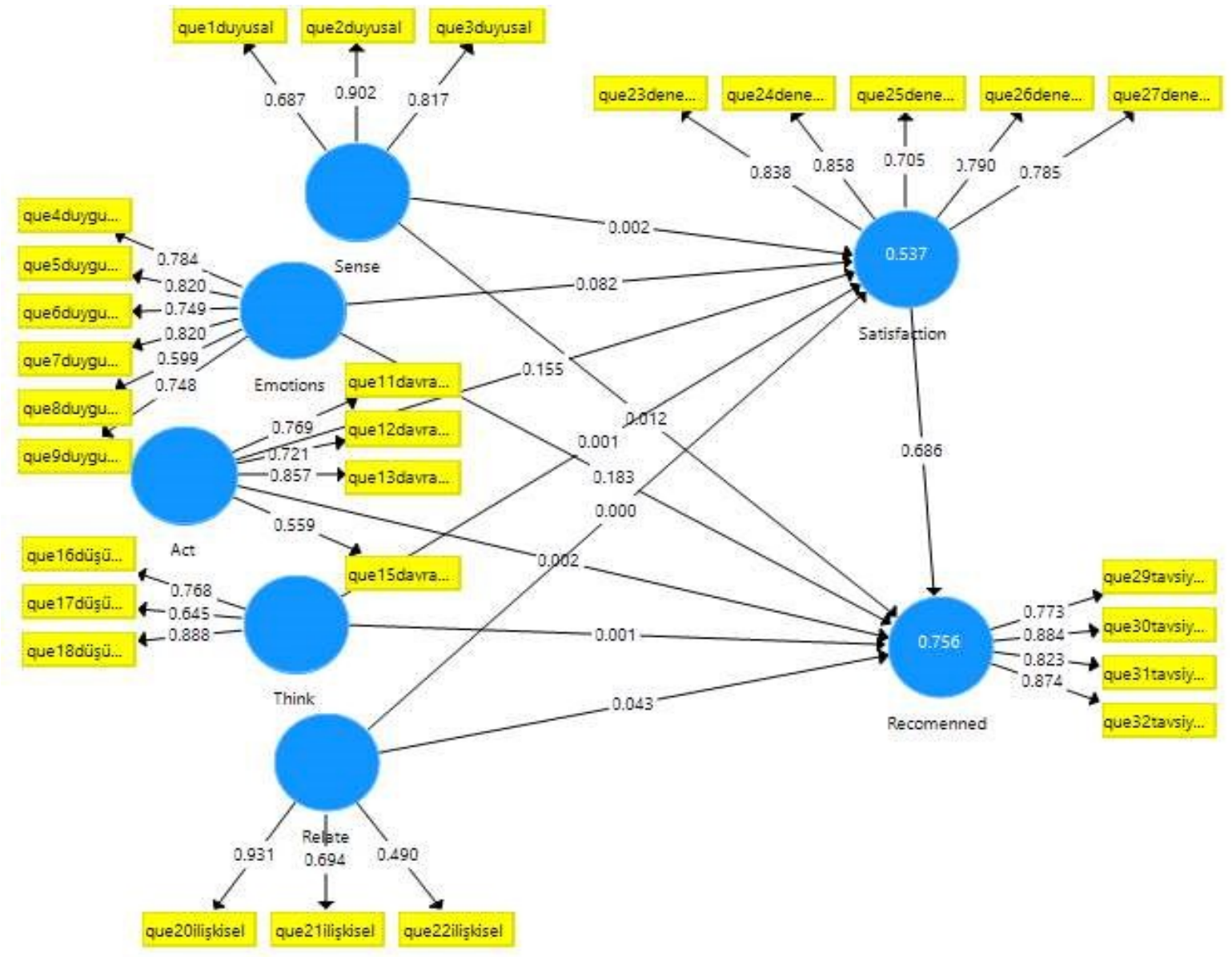

Şekil 2. Araştırma Modeline İlişkin SmartPLS-SEM Yapısal Model Sonuç Çıktısı 
Araştırmaya ilişkin $t$ değerlerinin ve anlamlılıklarının hesaplanması için araştırma modeli üzerinde Bootstrap (önyükleme) yöntemi kullanılmıştır. Önyükleme, PLS-SEM'deki tahmini değerlerin anlamlılık açısından test edilmesini sağlar (Henseler, Ringle ve Sinkovics 2009). Bu yöntem orijinal numuneden çok sayıda alt numune alarak, önceden belirlenmiş sayıda önyükleme örneği (örneğin, 5000) oluşturur. PLS algoritması, her önyükleme örneğinden elde edilen SEM sonuçlarını tahmin eder (örneğin, 5000 PLS-SEM tahminleri). Bu yöntemde araştırmanın $t$ değerleri ve anlamlılıklarını yeniden hesaplar. Bu yöntemle analiz sonrası ulaşılan t- test puanlarının hangilerinin $1.65(\alpha=0.10), 1,96(\alpha=0,05)$ ve 2,57 $(\alpha=0,01)$ kritik t değerleri üzerinde anlamlı olup olmadıkları belirlenmiştir. Şekil 3 'teki araştırma modeline ait parametrelere Tablo 6 ve Tablo 7' de verilmiştir.

Tablo 7. Araştırmaya Ait Yapısal Model Sınamasına İlişkin Ulaşılan Nihai Değerler

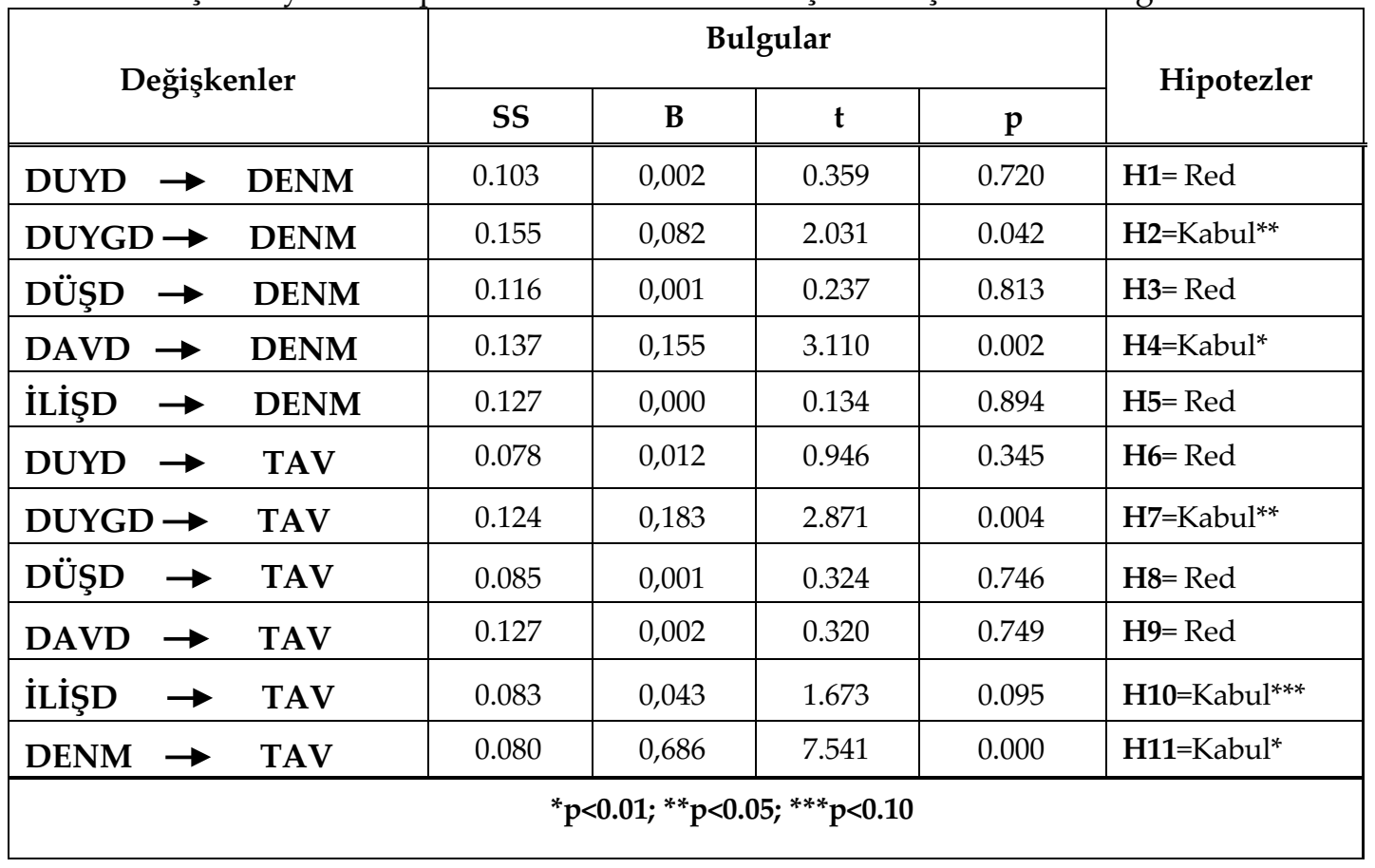

Araştırmada oluşturulan hipotezlerin test edilmesi sonucunda, deneyimsel pazarlama boyutlarından duygusal ve davranışsal deneyimlerin deneyimsel memnuniyeti olumlu yönde etkilediği; ancak duyusal, düşünsel ve ilişkisel deneyimlerin deneyimsel memnuniyeti etkilemediği ortaya çıkmıştır. Bu doğrultuda $\mathrm{H} 2$ ve $\mathrm{H} 4$ hipotezleri kabul edilmiş, $\mathrm{H} 1, \mathrm{H} 3$ ve H5 hipotezleri ise kabul edilmemiştir. Araştırma modelinde oluşturulan hipotezlerin test edilmesi sonucunda elde edilen bir diğer bulgu, duygusal ve ilişkisel deneyimlerin tavsiye etme niyetini olumlu yönde etkilediği; duyusal, davranışsal ve düşünsel deneyimlerin ise herhangi bir etkisinin olmadığıdır. Bu doğrultuda $\mathrm{H} 7$ ve $\mathrm{H} 10$ hipotezleri kabul edilirken, H6, H8 ve H9 hipotezleri ise kabul edilmemiştir. Araştırmada elde edilen bir diğer bulguya göre, deneyimsel memnuniyet tavsiye etme niyetini olumlu yönde etkilemiş ve bu doğrultuda H11 hipotezi kabul edilmiştir. 
Tablo 8. Araştırmaya Ait Yapısal Model Sınamasına İlişkin Aracılık Analizlerinin Sonuçları (Dolaylı Etkilere Yönelik Sonuçlar)

\begin{tabular}{|c|c|c|c|c|c|c|c|c|c|}
\hline \multirow{2}{*}{\multicolumn{5}{|c|}{ Değişkenler }} & \multicolumn{4}{|c|}{ Bulgular } & \multirow{3}{*}{$\begin{array}{l}\text { Hipotezler } \\
\text { H12= red }\end{array}$} \\
\hline & & & & & \multirow{2}{*}{$\frac{\text { Ss }}{0.061}$} & \multirow{2}{*}{$\frac{\text { B }}{0.053}$} & \multirow{2}{*}{$\frac{\mathbf{t}}{0.364}$} & \multirow{2}{*}{$\frac{\mathbf{p}}{0.716}$} & \\
\hline DUYD & $\rightarrow$ & DENM & $\rightarrow$ & TAV & & & & & \\
\hline DUYGD & $\rightarrow$ & DENM & $\rightarrow$ & TAV & 0.096 & 0.229 & 1,967 & 0.049 & H13=kabul ${ }^{* *}$ \\
\hline DÜŞD & $\rightarrow$ & DENM & $\rightarrow$ & TAV & 0.073 & 0.045 & 0.226 & 0.821 & H14= red \\
\hline DAVD & $\rightarrow$ & DENM & $\rightarrow$ & TAV & 0.093 & 0.200 & 2.761 & 0.006 & H15=kabul ${ }^{*}$ \\
\hline İLİŞD & $\rightarrow$ & DENM & $\rightarrow$ & TAV & 0.083 & 0.008 & 0.123 & 0.902 & H16= red \\
\hline
\end{tabular}

Araştırma modelindeki değişkenler için aracılık etkisini belirlemeye yönelik olarak oluşturulan hipotezlerin test edilmesi sonucunda, deneyimsel pazarlama boyutlarından duygusal deneyim ve davranışsal deneyim, deneyimsel memnuniyet üzerinden dolaylı olarak tavsiye etme niyetini etkilerken; duyusal, düşünsel ve ilişkisel deneyimlerin ise dolaylı etkisinin olmadığ 1 belirlenmiştir. Bu doğrultuda, H13 ve H15 hipotezleri kabul edilirken, H12, H14 ve H16 hipotezleri ise reddedilmiştir.

\section{TARTIŞMA VE SONUÇ}

2000'li yılların başından itibaren pazarlamaya yön veren teknolojik gelişmelere bağlı olarak iletişim ve reklam araçlarının artması tüketicilerin karar alma ve tercihlerinde değişimlerin başlangıcını tetiklemiştir. Aynı dönemin ürün ve hizmetlerinin demode, standart ve alışagelmiş işlevsel özellikleri ve faydalarının tüketicilerin zihinlerinde anlamlı bir fark yaratmaması geleneksel pazarlama anlayışının yetersiz kalmasına neden olmuştur. Geleneksel pazarlamaya kıyasla deneyimsel pazarlama, tüketicilerin sadece fonksiyonel özellikler ve fayda bağlamında değil duygusal ve sembolik değerler bağlamında da tatmin edilmesini amaçlamakta ve tüketicileri dinleyen, iş birliğine dayanan bir sürecin parçası olarak onlarla bağlantı kurmaktadır.

Golf oyuncularının duyusal deneyim düzeyleri oldukça yüksektir. Samsun Golf Kulübü tarafından sağlanan görsel ve diğer duyuların golf oyuncuları üzerinde güçlü etkiler bıraktığı ifade edilebilmektedir. Ayrıca golf oyuncuları bu kulübü duyusal açıdan ilgi çekici bulduklarını belirtmektedirler. Duygusal deneyimleri oldukça yüksek olan Golf oyuncuları kulüpte çalışanlarının güler yüzlü ve cana yakın olduğunu, kulübün konforlu ve samimi bir ortam sağladığını, kulüp ürünlerinin, çalışanlarının ve dekorasyonun bir bütün olarak sağladıkları atmosferin duygularına hitap ettiğini belirtmektedirler. Ayrıca golf oyuncuları, bu kulüpte keyifli vakit geçirdiklerini, kendilerini rahatlamış ve mutlu hissettiklerini ve bu kulüpte golf oynamanın eğlenceli olduğunu belirtmektedirler.

Golf oyuncuları bu kulübün ev, okul ya da iş yerleri dışında sosyalleşebileceği, vakit geçirebileceği güzel bir mekân olduğunu, kulübün bilgi artırıcı materyallerin (farklı alanlarda gazete ve dergi) bulunmasından ve kulübün internet kullanma imkanlarından hoşlandıklarını belirtmektedirler. Ayrıca golf oyuncuları bu kulübü ziyaret etmenin yaşam biçimini değiştirdiğini ve hayatının bir parçası haline geldiğini söylemektedirler. Katılımcıların deneyimsel pazarlama boyutlarından düşünsel deneyim düzeyleri kısmen yüksektir. Düşünsel 
deneyim ifadelerinden "Bu kulüpte düşünmek için rahat ortam vardır" ve "Bu kulüp ile ilgili son gelişmeleri kulübün internet sayfasından takip ederim" ifadelerine katılımın ortalaması düşük olmasına rağmen genel düşünsel deneyim düzeylerini ifade eden "kulüp benim yaratıcı düşünmeme yardımcı oluyor" ve "kulübün günlük gelişmelerini takip edebileceğim basılı ve görsel mecralar ile internet bağlantısı vardır" ifadeleri golf oyuncuları tarafından olumlu karşılanmıştır. Bu bağlamda düşünsel deneyim değişkenlerinden düşük değerler alan ifadelerde Golf Kulübü yönetimi tarafından iyileştirmelerin yapılması gerekmektedir.

Katılımcıların deneyimsel pazarlama boyutlarından ilişkisel deneyim düzeyleri kısmen yüksektir. Katılımcıların ilişkisel deneyim değişkenindeki "Bu kulüp sosyal çevremin gelişmesine yardımcı olur" ifadesine memnun yanıtlar vermelerine rağmen aynı değişkendeki "Bu kulübün paydaş//hissedarı olmak isterim" ile "Bu kulüp ile ilgili sosyal medyada (basında) çıkan haberleri takip ederim" ifadelerine verdikleri yanıtların kararsızlığı Golf Kulübü yönetimi tarafından dikkate alınıp gerekli iyileştirmeler sağlanmalıdır.

Katılımcıların deneyimsel memnuniyet düzeyleri oldukça yüksektir. Golf oyuncuları bu kulübün golf oynama ve sosyalleşme ihtiyacını karşıladığını, kulüpte geçirilen zamanın çok iyi geçirilmiş zaman dilimi olduğunu, bu kulübün beklentilerinin üzerinde olduğunu ve kulüpten çok iyi hizmet aldıklarını belirtmektedirler. Ayrıca golf oyuncuları kulübü her ziyaret ettiklerinde çok keyif aldıklarını ve kulübü gerçekten çok sevdiklerini söylemektedirler. Katılımcıların tavsiye etme niyeti düzeyleri oldukça yüksektir. Golf oyuncuları, kulüp hakkında olumlu şeyler söylediklerini, kulüp hakkında söylenecek birçok şey olduğunu, bu kulüpte golf oynadığını söylemekten gurur duyduğunu ve bu kulübü arkadaşlarına tavsiye edeceklerini ifade etmektedirler.

Araştırmada oluşturulan hipotezlerin test edilmesi sonucunda, deneyimsel pazarlama boyutlarından duygusal ve davranışsal deneyimlerin deneyimsel memnuniyeti olumlu yönde etkilediği; ancak deneyimsel pazarlama boyutlarından duyusal, düşünsel ve ilişkisel deneyimlerin deneyimsel memnuniyeti etkilemediği ortaya çıkmıştır. Bu doğrultuda $\mathrm{H} 2$ ve $\mathrm{H} 4$ hipotezleri kabul edilmiş, H1, H3 ve H5 hipotezleri ise kabul edilmemiştir. Aracı (2016), İzmir'in birinci sınıf yiyecek ve içecek restoranlarındaki örnek grup ile yapmış olduğu çalışmada deneyimsel pazarlamanın memnuniyet üzerine olan etkisini incelemiştir. Çalışma sonuçlara göre, duyusal, davranışsal, düşünsel deneyimler deneyimsel memnuniyeti etkilemezken; duygusal ve ilişkisel deneyimler etkilemiştir. Elde edilen sonuçlar incelendiğinde, H1 ve H3 hipotezlerinin aynı doğrultuda anlamlı etkisi yokken, $\mathrm{H} 2$ hipotezi aynı doğrultuda anlamlı ve pozitif yönde etkide bulunmuş, H4, H5 hipotezleri ise farklı sonuçlar vermiştir. Başar'ın (2015), İstanbul'daki bulunan Panorama 1453 Tarih Müzesi ziyaretçileriyle yaptığı çalışma bulgularına göre, deneyimsel pazarlama boyutlarından duyusal, davranışsal ve sosyal boyutların müşteri tatmini üzerinde etkisi olmazken, duygusal ve düşünsel boyutlarda etkisinin olduğu ortaya çıkmıştır. Çalışma sonuçları bu çalışma sonuçları ile karşılaştırıldığında, H1 ve H5 hipotezlerinin aynı doğrultuda anlamlı etkisi yokken, $\mathrm{H} 2$ hipotezi aynı doğrultuda anlamlı ve pozitif yönde etkilemiş, H2 ve H4 hipotezleri ise farklı sonuçlar vermiştir. Deligöz (2014), Ankara merkezde bulunan Starbucks ve Kahve Dünyasının tüketicileri ile yapmış olduğu çalışmasının amaçlarından biriside deneyimsel pazarlama boyutlarının deneyimsel memnuniyet üzerinde etkilerini incelemiştir. Araştırma sonuçlarına göre deneyimsel pazarlama boyutlarının (duyusal, duygusal, düşünsel, davranışsal ve ilişkisel) deneyimsel memnuniyet üzerinde olumlu yönde etkisi olduğu tespit edilmiştir. Elde edilen sonuçlar, bu çalışma sonuçları ile karşılaştırıldığında, $\mathrm{H} 2$ ve $\mathrm{H} 4$ aynı doğrultuda anlamlı ve pozitif yönde etkilemiş, H1, H3, H5 hipotezleri ise farklı sonuçlar vermiştir. Bu farklılığın oluşum nedenlerinin, çalışmanın iki farklı mekânda yapılmış olması, konunun golf hizmetlerinde tarafımızca ilk kez yapılıyor olması, Samsun Golf Kulübü'nün yeni kurulan bir kulüp olması gibi durumlardan kaynaklandığı 
değerlendirilmektedir. Ayrıca duyusal, düşünsel ve ilişkisel deneyim için kullanılan ifadeler, golf oyuncuları tarafından olumlu karşılanmasına rağmen kulübün sunduğu deneyim boyutlarının henüz yetersiz olması sebebiyle deneyimsel memnuniyet bu deneyimlerden etkilenmemiştir. Bu bağlamda kulüp yönetimi tarafından oyuncularda güçlü deneyimler yaratmaya odaklı gerekli iyileştirmelerin yapılması gerekmektedir.

Araştırma modelinde oluşturulan hipotezlerin test edilmesi sonucunda elde edilen bir diğer bulgu, deneyimsel pazarlama boyutlarının (duyusal, duygusal, düşünsel, davranışsal ve ilişkisel deneyimler) tavsiye etme niyeti üzerinde deneyimsel pazarlama boyutlarından duygusal ve ilişkisel deneyimleri olumlu yönde etkilerken; duyusal, davranışsal ve düşünsel deneyimleri ise etkilemediğini ortaya koymaktadır. Bu doğrultuda H7 ve H10 hipotezleri kabul edilirken, H6, H8 ve H9 hipotezleri ise kabul edilmemiştir. Akyıldız (2010), 2009 Rock'n Coke Festivali'ne katılan bireylerin boş zaman deneyimlerinin incelemesi amaçlı bir çalışma yürütmüştür. Çalışma sonuçları incelendiğinde deneyimsel pazarlama boyutlarından duyusal, duygusal, davranışsal ve ilişkisel deneyimlerin tavsiye etme niyetini olumlu yönde etkilediği anlaşılmıştır. Elde edilen sonuçlar bu çalışmanın sonuçları ile karşılaştırıldığında, H7 ve H10 hipotezleri aynı doğrultuda anlamlı ve pozitif yönde etkilerken, $\mathrm{H} 6$, $\mathrm{H} 8$ ve $\mathrm{H} 9$ hipotezleri farklı sonuçlar vermiştir. Bu farklılığın nedenleri, deneyim boyutlarının farklı hizmet alanlarında farklı düzeylerde farklı sonuçlar verebiliyor olması, golf kulübü oyuncularının golf hizmetinde yeni olmaları veya yaşatılan deneyimlerin oyuncuların yaşam tarzlarında henüz yer edinememesi gibi nedenlerden kaynaklandığı değerlendirilmektedir. Bu bakımdan kulüp yönetimi, oyuncuların yaşadıkları deneyimleri başkalarına aktarabileceği ve kulübü başkalarına tavsiye edebileceğini göz önünde bulundurarak, oyuncular için anlamlı ve unutulmaz deneyimler yaşatmalı ve gerekli iyileştirmeleri gerçekleştirerek süreci en iyi şekilde yönetmelidirler. Yapılacak olan iyileştirmelerin hem kulüp hem de oyuncular açısından karşıllıklı fayda sağlayacaktır.

Araştırmada elde edilen bir diğer bulguya göre, deneyimsel memnuniyet tavsiye etme niyetini olumlu yönde etkilemiş ve bu doğrultuda H11 hipotezi kabul edilmiştir. Kao, Huang ve Yang (2007), Tayvan'da süper basketbol liginde bir vaka çalışması incelemişlerdir. Araştırmacıların çalışmalarında deneyimsel memnuniyet ile tavsiye etme niyeti arasındaki ilişkiden elde ettikleri sonuçlar ile bu çalışmada elde edilen sonuçlar aynı doğrultudadır. Wu ve Li (2017), Makoa Tarihi Merkezinde bulunan turistlerle yapmış oldukları çalışmada, deneyimsel memnuniyetin tavsiye etme niyetine olan etkisini incelemişlerdir. Çalışmadan elde ettikleri sonuçlar bu çalışma ile elde edilen sonuçlar ile aynı doğrultudadır. Ayrıca Wu ve Ai'nin (2016), Hainan adasında golf turistleri ile yapmış oldukları çalışma sonucu, bu çalışmada elde edilen deneyimsel memnuniyetin tavsiye etme niyeti üzerindeki olumlu ve anlamlı sonuç ile örtüşmektedir. Bu sonuçlardan da anlaşılmaktadır ki, bugün artık tüketicinin aklını başından alacak, zihin ve kalplerinde iz bırakacak deneyimler, işletmeler adına deneyimsel memnuniyeti sağlayarak tavsiye etme niyetini güçlendirecektir.

Araştırmanın akademik değerinden yola çıkarak, gelecekte konuya ilişkin yapılacak çalışmalara sunulan öneriler, araştırmanın Türkiye'nin diğer illerinde, özellikle golf turizmimin yoğun yaşandığı Akdeniz illerinde, büyük ölçekli ve geniş kitlelerle yapılabileceğidir. Ayrıca gelecek çalışmaların yabancı oyuncuları örnekleme alçak şekilde geliştirilmesi karşılaştırmalı çalışmaların yapılması literatüre önemli katkılar sağlayabilir. Golf turizmde yapılan bu araştırma ayrıca kültür sanat faaliyetleri bağlamında Samsun'da bulunan Samsun Devlet Opera ve Balesi izleyicileri, Gazi Müzesi ve Kızılırmak Deltası Kuş Cenneti ziyaretçileri ile de gerçekleştirilebilir. 


\section{KAYNAKÇA}

Afthanorhan, W. M. A. B. W. (2013). A comparison of partial least square structural equation modeling (PLS-SEM) and covariance based structural equation modeling (CB-SEM) for confirmatory factor analysis, International Journal of Engineering Science and Innovative Technology, 2(5), 198-205.

Aracı, E.Ü. (2016). Deneyimsel Pazarlamanın Müşteri Tatmine ve Davranışsal Niyete Etkisi: Yiyecek İcecek İşletmelerinde Bir Uygulama, Yayınlanmış Doktora Tezi, Adnan Menderes Üniversitesi Sosyal Bilimler Enstitüsü Turizm İşletmeciliği, Aydın.

Baloglu, S. (2002). Dimensions of customer loyalty: separating friends from well-wishers, The Cornell Hotel and Restaurant Administration Quarterly, 43(1), 47-59.

Batı, U. (2018). Markethink ya da Farkethink: Deneyimsel Pazarlama ve Duyusal Markalama, İstanbul: Destek Yayınları.

Bagozzi, R. P., and Yi, Y. (1988). On the evaluation of structural equation models, Journal of the Academy of Marketing Science, 16(1), 74-94.

Başar, B. (2015). Kültür ve Sanat Faaliyetlerinde Deneyimsel Pazarlamanın Müşteri Sadakatine Etkisi, Yayınlanmış Yüksek Lisans Tezi, Gazi Üniversitesi Sosyal Bilimler Enstitüsü, Ankara.

Bigne, J.E., Andreu, L., and Gnoth, J. (2005). The theme park experience: An analysis of pleasure, arousal and satisfaction, Tourism Management, 26 (6), 833-844.

Brakus, J.J., Schmitt, H. B., and Zarantonello. (2009). Brand Experience: What Is It? How Is It Measured? Does It Affect Loyalty, Journal of Marketing, 73, 52-68.

Chang, P.L., and Chieng, M.N. (2006). Building consumer-brand relationship: A cross cultural experiential view, Psychology and Marketing, 23(11), 927-959.

Chin, W. W., and Newsted, P. R. (1999). Structural Equation Modeling Analysis with Small Samples Using Partial Least Squares, Statistical Strategies for Small Sample Research, 1(1), 307-341.

Costa, S. B., Claro, D. P., and Bortoluzzo, A. B. (2018). The influence of customer value on word of mouth: a study of the financial services company in Brazil, Revista Brasileira de Gestão de Negócios, 20(2), 210-231.

Demirtaş, M. C. (2017). Limitlerin Ötesini Deneyimlemek: Bir Deneyimsel Pazarlama Çabası Örneği Olarak Nike Sub 2, Kırklareli Üniversitesi İktisadi ve İdari Bilimler Fakültesi Dergisi, 6(3), 4657.

Deligöz, K. (2016). Deneyimsel Pazarlama, Ankara: Siyasal Kitabevi.

Erbaş, A.P. (2010). The Effect of Experiential Marketing on Customer Satisfaction and Loyalty: A Study on Starbucks, Yayınlanmamış Yüksek Lisans Tezi, Marmara Üniversitesi, İstanbul.

Fornell, C., Johnson, M. D., Anderson, E. W., Cha, J., and Bryant, B. E. (1996). The American customer satisfaction index: nature, purpose, and findings, Journal of Marketing, 60(4), 7-18.

Günay, G.N. (2008b). Hizmet Pazarlamasından Deneyimsel Pazarlamaya: Bir Güzellik Merkezinde Uygulama, Ulusal Pazarlama Kongresi, Pazarlamada Yeni Yaklaşımlar Bildirileri, 25-29 Ekim 2008, Nevşehir, 64-72.

Günay, G.N. (2009). Deneyimsel Pazarlama ve Mekân Oluşturma, Pazarlama ve İletişim Kültürü dergisi, 27(1), 30-34.

Gürkan, Bülent; Samsun 2019 Turkish Airlines Challenge, Golf Dünyası Dergisi, 116, (Nisan 2019), 26-32. 
Hair, J. F., Ringle, C. M., and Sarstedt, M. (2013). Partial least squares structural equation modeling: Rigorous applications, better results and higher acceptance, Long range planning, 46(12), $1-12$.

Hair, F. Jr, J., Sarstedt, M., Hopkins, L., and G. Kuppelwieser, V. (2014). Partial Least Squares Structural Equation Modeling (PLS-SEM) An Emerging Tool in Business Research, European Business Review, 26(2), 106-121.

Holbrook, M. B. (2000). The millennial consumer in the texts of our times: Experience and Entertainment, Journal of Marco Marketing, 21(2), 178-192.

Holbrook, M.B., and Hirschman, E.C. (1982). The Experiential Aspects of Consumption: Consumer Fantasies, Fellings, and Fun, Journal of Consumer Research, 9,132-140.

Hulland, J. (1999). Use of partial least squares (PLS) in strategic management research: A review of four recent studies, Strategic Management Journal, 20(2), 195-204.

Henseler, J., Ringle, C. M., and Sinkovics, R. R. (2009). The use of partial least squares path modeling in international marketing, In New Challenges to International Marketing. Emerald Group Publishing Limited.

Kao, F.Y., Huang, S.L., and Yang, H.M. (2007). Effects of Experiential elements on Experiential satisfaction and loyalty intentions: A case study of the super basketball league in Taiwan, International Journal of Revenue Management, 1(1), 79-96.

Kao, F.Y., Huang, S.L., and Wu, H.C. (2008). Effects of Theatrical Elements on Experiential Quality A Loyalty Intentions for Theme Parks, Asia Pacific Journal of Tourism Research, 13 (2), 163-174.

Kotler, P. (2017). A'dan Z'ye Pazarlama, (Çev. Aslı Kalem Bakkal). İstanbul: Kapital Medya Hizmetleri.

Kristensen, K., Martensen, A., and Gronholdt, L. (2000). Customer satisfaction measurement at post Denmark: results of application of the European customer satisfaction index methodology, Total Quality Management, 11(7), 1007- 1015.

Lagiewski, R. and Zekan, B. (2006). Experiential Marketing of Tourism Destinations. [Online] http://scholarworks.rit.edu/other/633. pdf> [Erişim Tarihi: 22.04.2015].

McCole, P. (2004). Refocusing Marketing to Reflect Practice: The Changing Role of Marketing for Business, Marketing Intelligence \& Planning 22(5), 531-539.

McAlexander, J.H., Schouten, J. W., and Koenig, H.F. (2002). Building brand community, Journal of Marketing, 66 (1), 38-54.

Nadiri, H., and Günay, G.N. (2013). An Empirical Study to Diagnose the Outcomes of Customers Experiences in Trendy Coffee Shops, Journal of Business Economics and Management, 14(1), 22-53.

Oliver, R.L. (1980). A cognitive model of the antecedents and consequences of satisfaction decisions, Journal of Marketing Research, 17, 460-469.

Oliver, R.L. (1993). Cognitive, affective and attribute bases of the satisfaction response, Journal of Customer Research, 20, 418-100.

Oliver, R., and Westbrook, R. (1993). Profiles of consumer emotions and satisfaction in ownership and usage, Emotion, 6(13), 12-27.

Olya, H. (2017). Partial Least Squares Based Structural Equation Modeling (PLS-SEM), Global Conference on Services Management, 3-7 October, Volterra, Italy. 
Pine, B.J., and Gilmore, J.H. (2001). Welcome to the Experience Economy, Health Forum Journal, 44 (5), 10-16.

Pine, B.J and Gilmore, J.H. (2002). Customer experience places: the new Offering Frontier, Strategy $\mathcal{E}$ Leadership, 30 (4), 4-11.

Rahim, A. G., Ignatius, I. U., and Adeoti, O. E. (2012). Is customer satisfaction an indicator of customer loyalty, Australian Journal of Business and Management Research 2 (7), 14-20.

Reichheld, F.F. (2003). The One Number You Need to Grow, Harvard Business Review, 81 (12), 4654 .

Schmitt, B. (1999a). Experiential Marketing, Journal of Marketing Management, 15(1-3), 53-67.

Schmitt, B. (1999b). Experiential Marketing, How to Get Customers to Sense, Feel, Think, Act, Relate to Your Company and Brands, New York: The Free Press.

Suryawan, S. (2013). Analisa hubungan antara experential marketing, Customer satisfaction dan customer loyalty cafe nona manis grand city mall Surabaya, Jurnal Strategi Pemasaran, 1(2), 1-10.

Storbacka, K., Standvik, T., and Grönroos. (1994). Managing customer relations for profit: The dynamics of relationship Quality, International Journal of Stress Management, 5 (5). 21-38.

Thompson, R., Barclay, D. W., and Higgins, C. A. (1995). The partial least squares approach to causal modeling: Personal computer adoption and use as an illustration, Technology studies: special issue on Research Methodology, 2(2), 284-324.

Tsai, S. (2005). Integrated Marketing as Management of Holistic Consumer Experience, Business Horizons, 48, 431-441.

Ünal, S., Akkuş, G., ve Akkuş, Ç. (2014). Yiyecek İçecek İşletmelerinde Atmosfer, Duygu, Memnuniyet ve Davranışsal Sadakat İlişkisi, Gazi Üniversitesi Turizm Fakültesi Dergisi, (1), 23-49.

Ueacharoenkit, S. (2013). Experiential marketing-A consumption of fantasies, feelings and fun. An investigation of the relationship between brand experience and loyalty within the context of the luxury cosmetics sector in Thailand, Doctoral dissertation, Brunel University Brunel Business School PhD Theses.

Wang, W., Chen, J.S., Fan, L., and Lu, J. (2012). Tourist Experience and Wetland Parks: A Case of Zhejiang, China, Annals of Tourism Research, 39(4), 1763-1778.

Wu, H. \& Ai, C. (2016). Synthesizing the Effects of Experiential quality, excitement, equity, Experiential satisfaction on Experiential loyalty for the golf industry: The case of Hainan Island, Journal of Hospitality and Tourism Management, 29, 41-59.

Wu, Hung-Che and Li, Tao. (2017). A Study of Experiential Quality, Perceived Value, Heritage Image, Experiential Satisfaction, and Behavioral Intentions for Heritage Tourists, Journal of Hospitality \& Tourism Research, 41(8), 904- 944.

Wong, K. K. K. (2013). Partial least squares structural equation modeling (PLS-SEM) techniques using SmartPLS, Marketing Bulletin, 24(1), 1-32.

Yang, Y.C. (2009). The study of Repurchase Intentions in Experiential Marketing - An Empirical Study of the Franchise Restaurant, International Journal of Organizational Innovation, 2(2), 245-261.

You-Ming, C. (2010). Study on The Impacts of Experiential Marketing and Customers' satisfaction Based on Relationship Quality, International Journal of Organizational Innovation (Online), 3(1), 189209. 
Yuan, Y. E., and Wu, C. K. (2008). Relationships Among Experience Marketing, Experiential Value, and Customer Satisfaction, Journal of Hospitality \& Tourism Research, 32(3), 287-410. 